\title{
Accumulation and Retention of Cesium-137 by the Common Goby
}

\author{
Ken-ichi Kimura* \\ (Accepted June 20, 1983)
}

\begin{abstract}
Accumulation and retention of ${ }^{137} \mathrm{Cs}$ by the common goby, Acanthogobius flavimanus from environmental water and food were investigated in order to obtain quantitative information on the food chain transfer of the nuclide in coastal sea environment.

It was found that the accumulation of ${ }^{187} \mathrm{Cs}$ by the fish from water and food showed a gradual increasing tendency during the experimental period and required long period to reach an equilibrium level.

Using a single exponential model, it was estimated that the accumulation of ${ }^{137} \mathrm{Cs}$ by the fish required more than 90 days to reach the equilibrium state.

From the experimental results, it was suggested that the relative contribution of food in the accumulation of ${ }^{137} \mathrm{Cs}$ by the fish was comparatively higher in comparison with direct absorption.
\end{abstract}

The radionuclides, Cesium-137 and Cesium-134, are important constituents of aqueous radioactive effluent discharged from nuclear fuel reprocessing and nuclear power stations. ${ }^{1)}$ These radionuclides are released mainly into estuaries and coastal sea environment.

According to recent extensive studies by Mitchell (1977) based on the results of the survey on the biological distribution of the radioactivity in the Irish Sea due to the discharge of the radioactive effluent from the Windscale Works, it is reported that Cesium-137 and Cesium-134 are major contaminants found in marine fishes. ${ }^{2)}$

Morgan investigated the accumulation of Cesium-137 by a wide range of marine fish from sea water alone and obtained concentration factors varying between 1.6 and 9.2 from the short-term experiments of 28 days. ${ }^{3)}$

Similarly, Bryan showed the low concentration factors of ${ }^{194} \mathrm{Cs}$ ranging between 1.2 and 14 for a number of marine invertebrates. ${ }^{4}$

Jefferies and Hewett investigated the accumulation of ${ }^{187} \mathrm{Cs}$ by the Plaice Pleuronectes platessa and the Thornback ray Raja clavata from environmental water over a period of 2 years and found that the observed values of concentration factor for ${ }^{187} \mathrm{Cs}$ in these fishes were in good agreement with the steady-state concentration factors estimated using a single exponential model ${ }^{5)}$

Pentreath and Jefferies examined the Cesium137 intake from food and water for the Plaice Pleuronectes Platessa collected from the Cumber- land coastal area and found that approximately $50 \%$ was attributable to food in the accumulation of ${ }^{137} \mathrm{Cs}$ by the fish.

The present paper is concerned with the accumulation and retention of ${ }^{137} \mathrm{Cs}$ by a coastal sea fish from water and food, and some quantitative considerations on the relative contribution from water and food in the accumulation of ${ }^{137} \mathrm{Cs}$ by the fish are discussed.

\section{Materials and Methods}

Carrier free Cesium-137 used in the present experiment was obtained in the form of Cesium Chloride in $0.56 \mathrm{M} \mathrm{HCl}$ solution from the Radiochemical Center, Amersham. It has a long physical half-life ( 30 years).

Marine polychaete worm, Nereis japonica and common goby, Acanthogobius flavimanus were used as experimental materials in this experiment.

In order to investigate the accumulation and retention of ${ }^{187} \mathrm{Cs}$ by the fish from environmental water, five common gobies with 27 grams in average body weight were placed into 40 liters of filtered sea water to which approximately 400 micro-curies of ${ }^{187} \mathrm{Cs}$ were added. In the uptake experiment, they were reared in the radioactive sea water for 21 days to follow the uptake pattern of ${ }^{187} \mathrm{Cs}$ after the concentration of the radioactivity in the rearing sea water reached a constant level. During the experimental period, they were fed on inactive polychaete worms every 3 days.

* Division of Environmental Health, National Institute of Radiological Sciences, Anagawa-4, Chiba 260, Japan (木村健一：放射線医学総合研究所環境衛生研究部). 
The uptake of ${ }^{137} \mathrm{Cs}$ by the fish was expressed in terms of concentration factor (C. F.), i.e., the ratio of the nuclide content in whole body to that in environmental water of the same weight.

After the cessation of the uptake experiment, some of the individuals were placed in non-active sea water and reared with inactive worms for 14 days to follow the retention pattern of ${ }^{187} \mathrm{Cs}$ accumulated from sea water.

On the other hand, in order to obtain quantitative information on the transfer of ${ }^{197} \mathrm{Cs}$ from food organism to the predator, highly radioactive food was made by rearing the polychaete worms in 4 liters of filtered sea water containing 400 microcuries of ${ }^{287} \mathrm{Cs}$ for 5 days. The labelled polychaete worms were reared in non-active sea water for 24 hours to remove the surface contamination.

In a single feeding experiment, the labelled worm was administered to each of four common gobies with 17 grams in average body weight. They were reared with inactive worms in non-active sea water during a period of 22 days to observe the retention pattern of ${ }^{137} \mathrm{Cs}$.

In the multiple feeding experiment, the labelled worm was administered daily to each of five common gobies with 25 grams in average body weight for successive 8 days. The concentration of the radioactivity in the food administered during the feeding experimental period showed considerable variation. These fish were reared in non-active sea water during this period to observe the accumulation pattern of ${ }^{137} \mathrm{Cs}$ from food.

After the cessation of daily feeding experiment, they were reared with non-active sea water for further 14 days to follow the retention pattern of accumulated ${ }^{187} \mathrm{Cs}$ by the fish.

In the uptake and retention experiments, they were reared in a perforated polyacryl container placed in an aquarium containing 40-50 liters of sea water.

In the case of the retention experiments, the rearing water was frequently replaced to prevent a buildup of waste product. The aquaria were kept at $20-22^{\circ} \mathrm{C}$ during the experimental period.

Whole-body counting of the live fish was carried out by use of "Armac" small animal counter (Packard Inst., Co.).

\section{Results and Discussion}

Whole-body accumulation of ${ }^{197} \mathrm{Cs}$ by the common goby from sea water was followed during a period of 21 days.

As shown in Fig. 1, it was found that the accumulation of ${ }^{197} \mathrm{Cs}$ by the fish under a constant level of the radioactivity of the sea water continued to increase gradually during the experimental period and seemed to require considerably long time to reach the equilibrium level. The concentration factor for ${ }^{137} \mathrm{Cs}$ in the fish obtained at the end of the experiment was $4.2 \pm 0.8$ (Table 1).

Similarly, Hiyama and Shimizu found that the accumulation of ${ }^{134} \mathrm{Cs}$ by the muscle of the common goby from sea water continued to increase slowly during the experimental period of 20 days and the time to reach half of the equilibrium level was more

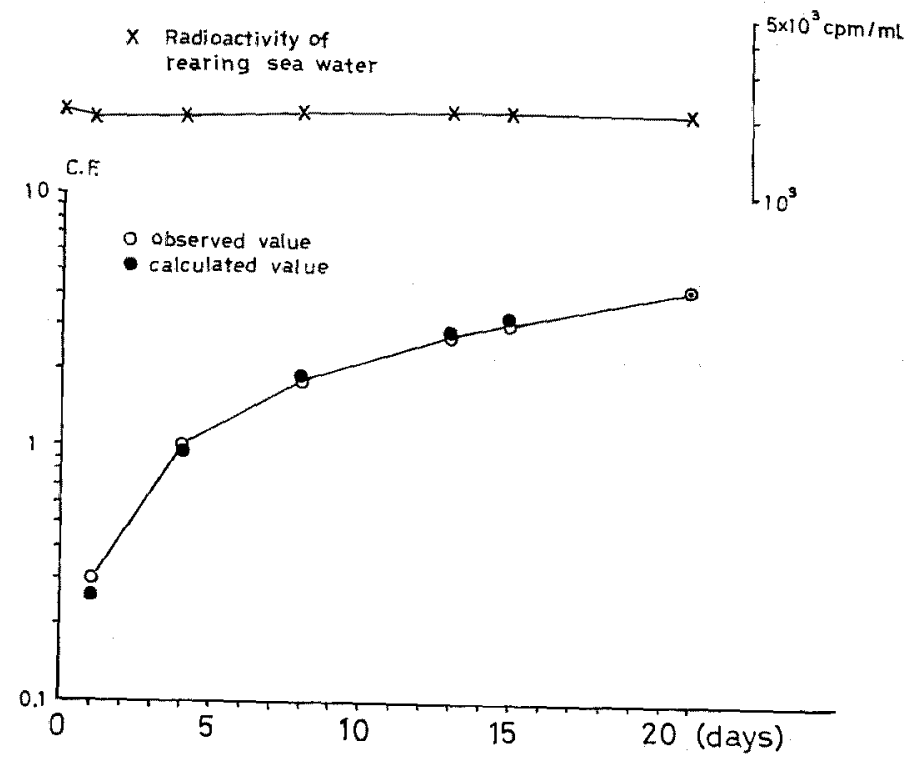

Fig. 1. Accumulation of ${ }^{137} \mathrm{Cs}$ by the common goby from sea water. 
Table 1. Concentration factor for ${ }^{137} \mathrm{Cs}$ in the common goby obtained at the end of the experiment

\begin{tabular}{|c|c|c|}
\hline \multicolumn{2}{|c|}{$\begin{array}{c}\text { Body weight } \\
\text { (g) }\end{array}$} & $\begin{array}{l}\text { Concentration } \\
\text { factor }\end{array}$ \\
\hline & 18.6 & 5.3 \\
\hline & 24.1 & 4.8 \\
\hline & 25.5 & 3.7 \\
\hline & 31.5 & 3.8 \\
\hline & 33.1 & 3.4 \\
\hline Average & 26.6 & 4.2 \\
\hline
\end{tabular}

Table 2. Biological half-lives for ${ }^{137} \mathrm{Cs}$ in the common goby which was reared in non-active sea water during 14 days after the cessation of the uptake experiment from sea water

\begin{tabular}{|c|c|c|c|}
\hline & $\begin{array}{l}\text { Body } \\
\text { weight } \\
\text { (g) }\end{array}$ & $\begin{array}{l}\text { Biological } \\
\text { half-life } \\
\text { (days) }\end{array}$ & $\begin{array}{l}\text { Biological } \\
\text { elimination } \\
\text { constant }(\lambda)\end{array}$ \\
\hline & 18.6 & 19 & 0.036 \\
\hline & 24.1 & 18 & 0.038 \\
\hline & 25.5 & 37 & 0.019 \\
\hline & 31.5 & 37 & 0.019 \\
\hline & 33.1 & 39 & 0.018 \\
\hline Average & 26.6 & 27 & 0.026 \\
\hline
\end{tabular}

than 30 days. ${ }^{\mathrm{T}}$ ?

The retention pattern of ${ }^{187} \mathrm{Cs}$ in the fish accumulated from sea water is shown in Fig. 2. As shown in the figure, it was observed that ${ }^{137} \mathrm{Cs}$ incorporated in the fish was eliminated with the biological half-lives of 18-39 days (Table 2).

The biological half-lives for ${ }^{187} \mathrm{Cs}$ in the common goby was nearly identical with those obtained from the uptake curve of ${ }^{134} \mathrm{Cs}$ in the marine goby Chasmichthys gulosus and the retention curve of ${ }^{137} \mathrm{Cs}$ in the post-larval flounder Paralichthys dentatus. ${ }^{8,8)}$

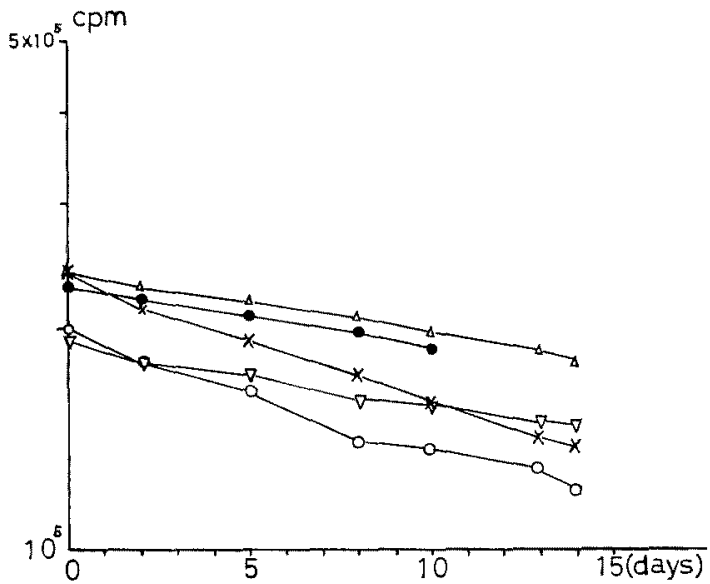

Fig. 2. Whole-body retention of ${ }^{137} \mathrm{Cs}$ in the common goby accumulated from sea water.

Symbols denote different individuals.

After the retention study, the gobies were dissected into various organs to observe the tissue distribution of ${ }^{187} \mathrm{Cs}$ in the fish body. The distribution of ${ }^{137} \mathrm{Cs}$ in various organs of the fish showed the highest value in the muscle and the lowest in the gill (Table 3).

Using a single exponential model, the steadystate concentration factor for ${ }^{187} \mathrm{Cs}$ in the fish and the time to reach $90 \%$ and $50 \%$ of the equilibrium level were estimated.

The rate at which the fish accumulates the radioactivity from environmental water may be estimated by the following formula,

$$
Q_{\mathrm{s}}=\frac{U K}{\lambda}\left(1-\mathrm{e}^{-\lambda t}\right)
$$

Where $Q_{t}$ expresses the radioactivity accumulated in the fish at time $t(\mathrm{cpm} / \mathrm{g})$ and the fish is assumed to take up the radionuclide at a constant

Table 3. Distribution of ${ }^{137} \mathrm{Cs}$ in various organs of the common goby which was reared in nonactive sea water during 14 days after the cessation of the uptake experiment from sea water

\begin{tabular}{lccc}
\hline \multicolumn{1}{c}{ Organ } & \% of body weight & Distribution (\%) & Relative concentration* \\
\hline Muscle & 32.5 & 40.6 & 1 \\
Head & 19.0 & 12.9 & 0.56 \\
Scale, Skin & 13.3 & 15.4 & 0.93 \\
Fin & 3.9 & 2.6 & 0.50 \\
Bone & 9.0 & 10.2 & 0.91 \\
Gill & 2.4 & 1.6 & 0.57 \\
Liver & 6.0 & 3.3 & 0.43 \\
Digestive tract & 3.9 & 3.2 & 0.75 \\
Other viscera & 10.6 & 6.1 & 0.53 \\
\hline Residue & & 4.7 & \\
\hline Each valve represents the average value of four specimens. * The ratio of the nuclide content in the organ to that in the muscle of \\
the same weight.
\end{tabular}


rate $U$ from the environmental water, and the accumulated radioactivity in the fish is eliminated at a constant rate $\lambda$. The average concentration of the radioactivity in the rearing water $(\mathrm{K})$ during the experimental period was $2100 \mathrm{cpm} / \mathrm{ml}$.

The theoretically calculated values were fitted well to the observed values from the uptake experiment using daily intake rate $(U ; 0.256)$ and biological elimination constant $(\lambda ; 0.026)$ obtained from the retention curve of ${ }^{137} \mathrm{Cs}$ in the fish accumulated from water.

From the above-mentioned formula, the time course of the accumulation of ${ }^{187} \mathrm{Cs}$ can be given as follows;

$$
Q_{\mathrm{t}}=20700\left(1-\mathrm{e}^{-0.028 t}\right),
$$

As shown in Fig. 1, the observed concentration factors for ${ }^{137} \mathrm{Cs}$ in the fish obtained from the uptake experiment was consistent with the calculated values using the formula.

Using a single exponential model, it was estimated that the time to reach $90 \%$ and $50 \%$ of the equilibrium level was 89 days and 27 days, respectively and the steady-state concentration factor for ${ }^{137} \mathrm{Cs}$ in the fish was 9.9.

Hiyama and Shimizu estimated the steady-state concentration factor of ${ }^{134} \mathrm{Cs}$ to be 7 by applying an exponential model to the uptake curve of ${ }^{184} \mathrm{Cs}$ in the marine goby from environmental water. ${ }^{8)}$

Patel reported that the concentration factor for ${ }^{134,137} \mathrm{Cs}$ in marine fish ranged from 2 to 36 based on the results of the uptake experiments from sea water alone carried out by many investigators, ${ }^{10)}$

In order to examine the transfer of ${ }^{197} \mathrm{Cs}$ from food organism to the predator, the fish was fed on contaminated polychaete worm.

The uptake and retention pattern of ${ }^{187} \mathrm{Cs}$ in the fish following a single oral administration of contaminated worm are shown in Fig. 3.

It was found that ${ }^{187} \mathrm{Cs}$ incorporated in the fish showed an initial slight decrease for the first few days followed by a slower elimination pattern thereafter.

The absorption rate of ${ }^{137} \mathrm{Cs}$ (defined as the activity remaining 3 days after administration) following a single oral administration was $80 \%$ of the administered dose on an average.

Hiyama and Shimizu investigated the absorption rate for ${ }^{137} \mathrm{Cs}$ in several kinds of marine fishes and obtained the absorption rate varying $29 \%$ to $58 \%$ of the administered dose when fed on contaminated midge larva. ${ }^{11)}$

Aoyama and Inoue found that the absorption rate of ${ }^{137} \mathrm{Cs}$ in two species of fresh water fishes was $73 \%$ for the Cichlid, Astronotus ocellatus and $69 \%$ for the Pike when fed on contaminated fish, Oryzias latipes. ${ }^{12,18)}$

Kolehmainen and Nelson reported that the absorption rate of ${ }^{197} \mathrm{Cs}$ in the bluegill, Lepomis macrochirus varied from $30 \%$ to $70 \%$ according to the kind of the food administered. ${ }^{14}$ )

The absorption rate for ${ }^{187} \mathrm{Cs}$ in the common goby was conspicuously higher compared with that obtained from the feeding experiments of

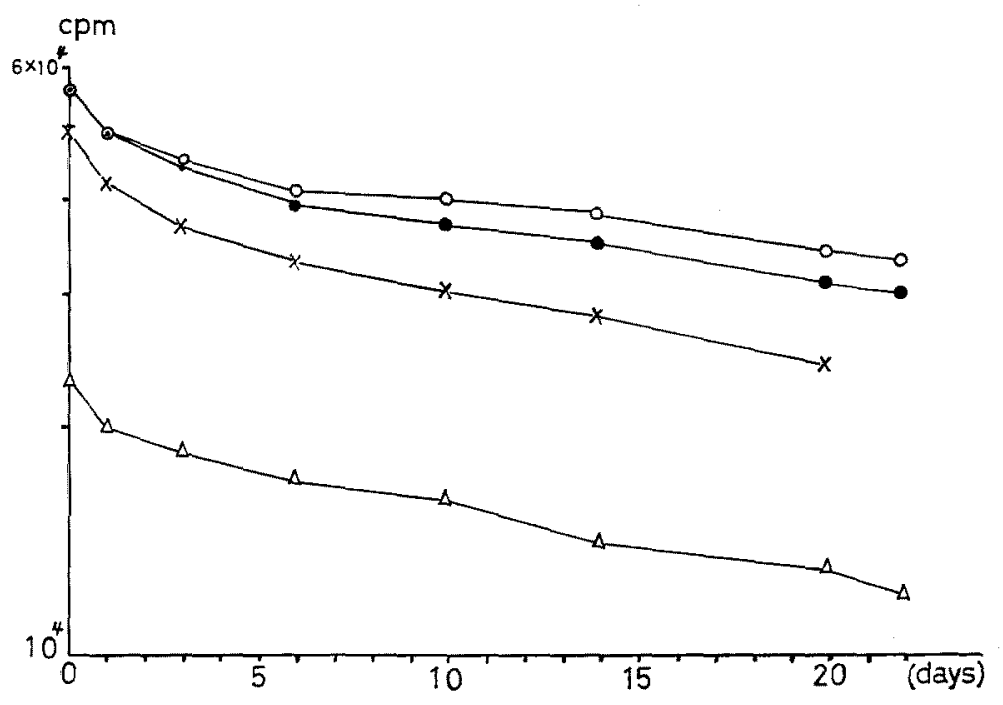

Fig. 3. Whole-body retention of ${ }^{137} \mathrm{Cs}$ in the common goby following a single oral administration of contaminated polychatee worm. Symbols denote different individuals. 
Table 4. Biological half-lives for ${ }^{137} \mathrm{Cs}$ in the common goby which was fed singly on contaminated polychaete worm

\begin{tabular}{|c|c|c|c|c|}
\hline & $\begin{array}{l}\text { Body } \\
\text { weight } \\
\text { (g) }\end{array}$ & $\begin{array}{c}\text { Biological } \\
\text { half-life } \\
\text { (days) }\end{array}$ & $\begin{array}{l}\text { Biological } \\
\text { elimination } \\
\text { constant }(\lambda)\end{array}$ & slow component \\
\hline & 11.8 & 30 & 0.023 & 6 th-20th day \\
\hline & 17.7 & 32 & 0.002 & 3 th-22th day \\
\hline & 18.4 & 50 & 0.014 & 6th-22th day \\
\hline & 19.7 & 41 & 0.017 & 6 th-22th day \\
\hline Average & 16.9 & 37 & 0.019 & \\
\hline
\end{tabular}

${ }^{100} \mathrm{Ru}$ and ${ }^{80} \mathrm{Co}$ by the common goby. ${ }^{10,107}$

The biological half-lives for ${ }^{187} \mathrm{Cs}$ in the fish were calculated using the biological elimination constant (0.019) obtained from the slower component of the retention curve of ${ }^{197} \mathrm{Cs}$. As seen in Table 4 , it was found that the biological half-lives for ${ }^{187} \mathrm{Cs}$ in the fish was 37 days on an average.

To observe the accumulation pattern of ${ }^{137} \mathrm{Cs}$ in the fish, the accumulation of ${ }^{137} \mathrm{Cs}$ following daily oral administration of contaminated worm was investigated for 8 days.

Fig. 4 showed the accumulation pattern of ${ }^{137} \mathrm{Cs}$ in a common goby which was fed daily on contaminated worm. In the feeding experiment, the common goby was fed mostly on the same amount of radioactive worm for 6 days, but, during the last two days of the experimental period, fed on considerably less amount of radioactive worm in comparison with the average daily administered dose $(122000 \mathrm{cpm})$ for the initial 6 days because of regurgitation of the food.

From the accumulation curve of ${ }^{137} \mathrm{Cs}$ in the fish, it was found that the accumulation of ${ }^{197} \mathrm{Cs}$ in the fish from food showed a gradual increasing tendency and seemed to require considerably long time to reach the equilibrium level as seen in the accumulation from water.

The rate at which the fish accumulates the total body burden of ${ }^{137} \mathrm{Cs}$ from food may be estimated by the following formula;

$$
Q_{\mathrm{t}}=\frac{I f}{\lambda}\left(1-\mathrm{e}^{-\lambda t}\right)
$$

Where $Q_{t}$ is total body burden at time $t, I$ is daily intake $(122000 \mathrm{cpm}), f$ is absorption rate $(80 \%)$ and $\lambda$ is biological elimination constant $(0.019)$.

From the above-mentioned formula, the time course of the body burden of ${ }^{187} \mathrm{Cs}$ in the fish at time $t$ can be expressed as follows;

$$
Q_{\mathrm{t}}=5143700\left(1-\mathrm{e}^{-0.019 t}\right) \text {, }
$$

As shown in Fig. 4, it was indicated that the

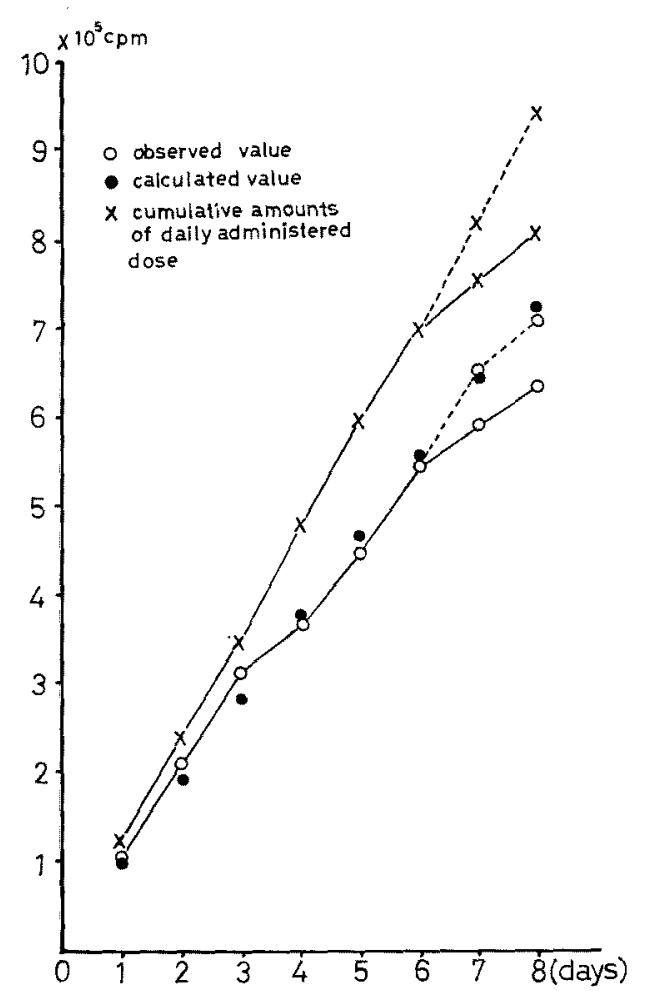

Fig. 4. Accumulation of ${ }^{137} \mathrm{Cs}$ by a common goby following daily oral administration of contaminated polychaete worm. The dotted lines of the accumulation curve of ${ }^{137} \mathrm{Cs}$ in the fish represent the expected values in the case of ingestion of radioactive worm $(122000 \mathrm{cpm})$ for the last two days of the experimental period.

theoretically calculated values was in fairly good agreement with the observed ones from daily feeding experiment. The accumulated radioactivity in the experimental fishes at the end of the feeding experiment was approximately $73 \%$ of total administered doses for the whole period (Table 5).

The elimination of accumulated ${ }^{187} \mathrm{Cs}$ by the fish from food showed a slow decreasing pattern with the biological half-lives of 33 days (Fig. 5 
Table 5. Retention rate of ${ }^{137} \mathrm{Cs}$ in the common goby at the end of the feeding experiment

\begin{tabular}{|c|c|c|c|c|}
\hline & $\begin{array}{l}\text { Body } \\
\text { weight } \\
\text { (g) }\end{array}$ & $\begin{array}{l}\text { Cumulative amounts of } \\
\text { daily administered dose } \\
(\mathrm{cpm})\end{array}$ & $\begin{array}{c}\text { Radioactivity accumulated } \\
\text { in fish } \\
(\mathrm{cpm})\end{array}$ & Retention rate \\
\hline & 19.6 & 407786 & 328060 & 80.4 \\
\hline & 20.3 & 392118 & 292640 & 74.6 \\
\hline & 24.5 & 838263 & 637751 & 76.1 \\
\hline & 27.7 & 373371 & 247049 & 66.2 \\
\hline & 33.9 & 544120 & 373482 & 68.6 \\
\hline Average & 25.2 & & & 73.2 \\
\hline
\end{tabular}

Table 6. Biological half-lives for ${ }^{137} \mathrm{Cs}$ in the common goby which was fed daily on contaminated polychaete worm

\begin{tabular}{|c|c|c|c|}
\hline & $\begin{array}{l}\text { Body } \\
\text { weight } \\
\text { (g) }\end{array}$ & $\begin{array}{c}\text { Biological } \\
\text { half-life } \\
\text { (days) }\end{array}$ & $\begin{array}{l}\text { Biological } \\
\text { elimination } \\
\text { constant }(\lambda)\end{array}$ \\
\hline & 19.6 & 35 & 0.020 \\
\hline & 20.3 & 30 & 0.023 \\
\hline & 24.5 & 33 & 0.021 \\
\hline & 27.7 & 37 & 0.019 \\
\hline & 33.9 & 30 & 0.023 \\
\hline Average & 25.2 & 33 & 0.021 \\
\hline
\end{tabular}

and Table 6).

From the accumulation curve of ${ }^{187} \mathrm{Cs}$ by the fish, it was estimated that the time to reach $90 \%$ and $50 \%$ of the equilibrium level was 121 days and 37 days, respectively.

The total body burden of ${ }^{137} \mathrm{Cs}$ at the equilibrium state from water and food was compared in order to elucidate the relative contribution from water and food in the accumulation of ${ }^{187} \mathrm{Cs}$ by the fish.

Assuming that the fish continued to ingest 1 gram ( $4 \%$ of the body weight/day) of the radioactive worm containing the same concentration of the radioactivity in the rearing sea water (e.g., C. F.; 1), the accumulation of ${ }^{187} \mathrm{Cs}$ in the fish through this food chain would reach about four times higher compared with the direct absorption. The concentration factor for ${ }^{197} \mathrm{Cs}$ in the polychaete worm Nereis diversicolor is reported to be 6.3 by Bryan. ${ }^{4}$ )

If the fish fed daily on radioactive worm having concentration factor of 6.3 , the accumulation of ${ }^{137} \mathrm{Cs}$ in the fish would reach 24 times higher in comparison with the direct absorption.

Hewett and Jefferies reported that the contribution of food in the accumulation of ${ }^{187} \mathrm{Cs}$ was 90\% for the Plaice Pleuronectes platesra and the Thornback ray Raja clavata from a comparison of the concentration factor in the environmental

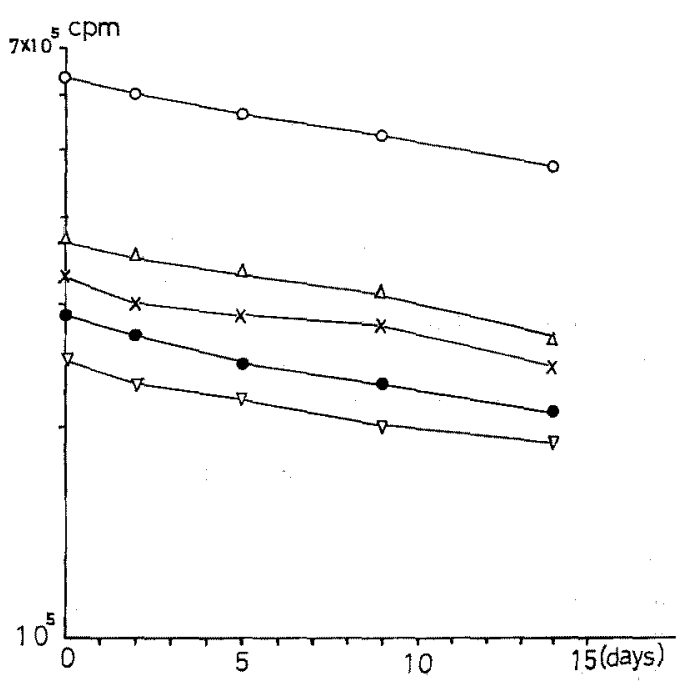

Fig. 5. Whole-body retention of ${ }^{137} \mathrm{Cs}$ in the common goby accumulated from food.

Symbols denote different individuals.

fish samples with that obtained from the aquaria studies on the uptake of ${ }^{187} \mathrm{Cs}$ from sea water only. ${ }^{17)}$

Pentreath and Jeffereies examined the Cesium137 intake from food and water for the Plaice Pleuronectes platessa collected from the Cumberland coastal area and suggested that approximately $50 \%$ was attributable to food in the accumulation of ${ }^{137} \mathrm{Cs}$ by the fish. ${ }^{\text {) }}$

The accumulation of radionuclide by fish from food may be influenced by various factors, i.e., daily feeding rate, the amount of food ingested, the concentration factor in food, and the absorption rate and the composition of food ingested.

It is known that the feeding habit of the common goby is omnivorous and feeds mainly annelida and amphipoda from the examination of the stomach content. ${ }^{18-20)}$

According to the ecological studies on the feeding of marine fish, the daily feeding ration of marine fish in nature showed considerably low value. ${ }^{21)}$ 
Thompson et al. (1972) reported that the average concentration factor in the edible part of marine fish was 40 for ${ }^{137} \mathrm{Cs}$ and 30 for $\mathrm{Cs}^{22)}$

Suzuki et al. (1973) found that the concentration factors for the muscles of marine fishes collected from the coasts of Japan were 11-81 for ${ }^{137} \mathrm{Cs}$ and $34-52$ for $\mathrm{Cs}^{23)}$ These concentration factors for ${ }^{137} \mathrm{Cs}$ and $\mathrm{Cs}$ in marine fishes are considered to be steady-state concentration factors attained through both pathways from water and food.

From the above-mentioned findings, it was suggested that the accumulation of ${ }^{187} \mathrm{Cs}$ by marine fish from water and food should require considerably long period to attain an equilibrium state and the relative contribution of food in the accumulation of ${ }^{137} \mathrm{Cs}$ was comparatively higher than in the case of direct absorption.

\section{Acknowledgements}

The author would like to appreciate Dr. R. ICHIKAWA of our institute for valuable suggestions and encouragements in the course of the present work, and Mr. H. KIMURA for his help to collect the experimental fish used in this study.

Co-operation of the stuffs of Branch of Nori cultivation station, the Chiba Prefectural Fisheries Experimental Station is also appreciated.

\section{References}

1) Report of the United Nations Scientific Committee on the Effects of Atomic Radiation 1977 report to the General Assembly, with annexes, Sources and Effects of Ionizing Radiation, pp. 165-222 (1977).

2) N. MrTCHELL: Radioactivity in Surface and Coastal Waters of the British Isles, 1976. Technical Report FRL 13 (1977).

3) F. Morgan: J. Mar. Biol. Ass. U.K., 44, 259271 (1964).

4) G. W. BRYAN: J. Mar. Biol. Ass. U.K., 43,519539 (1963).
5) D. F. JefFeries and C. J. Hewett: J. Mar. Biol. Ass. U.K., 51, 411-422 (1971).

6) R. J. Pentreath and D. F. Jefferies: J. Mar. Biol. Ass. U.K., 51, 963-976 (1971).

7) Y. Hiyama and M. Shimizu: Rec. of Oceanogr. Works in Japan, 7, 43-77 (1964).

8) Y. HiYama and M. Shimizu: In "Environmental Contamination by Radioactive Materials", IAEA, 463-476 (1969).

9) J. P. Baptist and T. J. Price: Fish. Bull., 206, 177-187 (1962).

10) B. PAtel: IAEA Technical Report Series, 167, 211-239 (1971).

11) Y. Hiyama and M. Shimizu: In "Ann. Rept. Mini. Educ. 1967, Radiation Effects-Coop. Res. (in Japanese)", 256, (1968).

12) I. Aoyama and Y. Inoue: J. Radia. Res., 14, 375-381 (1973).

13) I. Aoyama, Y. Inove, and Y. Inove: Water Res., 12, 831-836 (1978).

14) S. E. Kolehmainen and D. J. Nelson: The balances of ${ }^{137} \mathrm{Cs}$, stable cesium and the feeding rates of bluegill (Lepomis macrochirus Raf.) in White Oak lake. ORNL-4445 (1969).

15) K. Kimura and R. ICHIKAWA: Bull. Japan. Soc. Sci. Fish., 35, 434-440 (1969).

16) K. Kimura and R. Ichixawa: Bull. Japan. Soc. Sci. Fish., 38, 1097-1103 (1972).

17) C. J. Hewett and D. F. Jefferies: J. Fish. Biol., 9, 479-489 (1976).

18) F. Yasuda: Bull. Japan. Soc. Sci. Fish., 26, 653-662 (1960).

19) T. ToKioKa, E. Harada, and S. Nishimura: In "Marine ecology (in Japanese)", Tsukiji Book Company, 1972, pp. 126-138.

20) G. Yamamoto: In "Marine ecology (in Japanese)", Tokyo University Press, 1973, pp. 127156.

21) N. Ishiwata: Bull. Japan. Soc. Sci. Fish., 45, 561-565 (1979).

22) S. E. Thompson, C. A. Burton, D. J. Quinn, and C. N. Yook: Concentration factors of Chemical elements in edible aquatic organisms, UCRL50564 (1972).

23) Y. Suzuki Y. Nakamura, and T. Ueda: $J$. Raeiat. Res., 14, 382-391 (1975). 